\title{
Research Progress of Transcription Factor KLF4 in Lung Cancer
}

\author{
Minjun Dong ${ }^{1}$, Liang Luo ${ }^{2}$, Yunlu Jia ${ }^{3}$, Xianqiu Lư ${ }^{3}$, Yongcheng Liư ${ }^{1}$, and Yuan $s^{4 *}$ \\ ${ }^{1}$ Department of Surgical Oncology, Zhejiang University School of Medicine, China \\ ${ }^{2}$ Department of Gastroenterology, Zhejiang University School of Medicine, China \\ ${ }^{3}$ Zhejiang University School of Medicine, China \\ ${ }^{4}$ Department of Microbiology, The University of Hong Kong, Hong Kong SAR, China
}

Submission: March 13, 2017; Published: June 16, 2017

*Corresponding author: Shuofeng Yuan, Department of Microbiology, Li Ka Shing Faculty of Medicine, The University of Hong Kong, Hong Kong SAR, China, Tel: +852 22554380; Fax: +852 28551241; Email: yuansf@hku.hk

\begin{abstract}
Lung cancer is the leading cause of cancer mortality worldwide. While our understanding of the molecular events in the lung cancers are poor. In this report, we reviewed the current studies on a transcription factor named Krüppel-like Factor 4(KLF4) in lung cancer. Tissue studies showed that KLF4 expression was significantly decreased in non-small-cell lung cancer (NSCLC), while significant over expression in small-cell lung cancer (SCLC). On the cellular level of lung cancer, KLF4 regulate p21, SPARC, vimentin, b-catenin, VEGF-A, and cyclin D1, and it may enhance the lung tumor formation combined with K-ras mutation. Moreover, Numbl, NLK, Interleukin-27, miR-7, miR-10b, and miR-29, HOTAIR and HIF were able to regulate the KLF4 expression. We suggest that more understanding of the mode of KLF4 actions and its functional networks may lead to the development of novel therapeutics to improve current prospects for lung cancer prevention and cure.
\end{abstract}

Keywords: KLF4; Lung cancer; Embryonic Stem Cells; Malignancy

Abbreviations: NSCLC: Non Small Cell Lung Cancer; SCLC: Small Cell Lung Cancer; KLF4: KRÜPPEL Like Factor 4; SPARC: The Secreted Protein Acidic and Rich in Cysteine; HIF: Hypoxia Inducible Factor; HESC: Human Embryonic Stem Cells

\section{Introduction}

Lung cancer is the most common malignancy involving both genders and remains the main cause of cancer-related mortality worldwide. The two main histological groups are non-smallcell lung cancer (NSCLC) and small-cell lung cancer (SCLC). Approximately $85 \%$ of lung cancers are NSCLCs, which includes three major histological subtypes: Adenocarcinoma, squamous cell carcinoma and large-cell carcinoma. Despite the improving therapeutic approaches, the overall survival of lung cancer patients remains low. The 5-year survival for SCLC is lower compared with that of NSCLC (about 6\% vs. 18\%, respectively). Therefore, a better understanding of biomarkers associated with lung cancer may have clinical value in improving treatment selection and prediction, and may even set the base for the development of future novel targeted therapies.

Krüppel-like Factor 4 (KLF4) was initially identified as a zinc-finger transcription factor enriched in the epithelium of intestine and skin $[1,2]$ Later, it was detected in a variety of other tissues, such as thymus, cardiac myocytes and lymphocytes [3-
5] KLF4 plays an important role in the development and cell differentiation [6-8] In normal lung tissues, KLF4 is expressed in fibroblasts and airway epithelial cells, and was found to be the most significantly altered lung gene at birth [9]. As one of the four factors that induce pluripotent stem cells, KLF4 has a role in cell fate reprogramming and self-renewal of embryonic stem cells $[10,11]$ KLF4 is implicated as a tumor suppressor gene in the gastrointestinal tract epithelium [12,13], Bladder cancer [14] and medulloblastoma [15], but it may function as a transforming oncogene in breast cancer [16] and skin cancer [17]. In this article, we review the current understanding of the behavior of KLF4 in lung cancer.

\section{The KLF4 expression in lung cancer tissue}

The KLF4 expression level differs in present studies. $\mathrm{Hu}$ et al. [18] were the first to report the down regulation of KLF4 protein and mRNA in primary lung tumor tissues using western blot and real-time PCR, involving 25 non-small cell carcinoma 
[18]. Later, Naranjo Gómez et al. [19] reported high expression of KLF4 in neuroendocrine lung carcinomas, where KLF4 was positive in 23 of 35 large-cell neuroendocrine carcinomas, 10 of 10 tumor lets, 15 of 47 typical carcinoids and 18 of 18 SCLCs [19]. Then, Fadous-Khalife MC et al. [20] reported that a significant decrease in KLF4 expression was observed in nonsmall-cell lung cancer (NSCLC) compared with that in normal tissue, while significant over expression was detected in smallcell lung cancer. Furthermore, a higher rate of expression was observed in stage II, III and IV disease compared with stage I disease in NSCLC tissues [20]. Although the data is limited, it is more accepted that KLF4 is down-regulated in NSCLC and upregulated in SCLC. And because the NSCLCs are the absolute majority, most of the researches on the mechanisms of how KLF4 works in lung cancer used NSCLC models.

\section{The KLF4 associated network in Lung cancer \\ Regulation by KLF4}

Down regulation of KLF4 in primary tumor tissues was associated with either down-regulating of p21, up-regulation of cyclin D1, or both. This is consistent with other studies indicating that KLF4 plays important roles in regulating p21 and cyclin D1 expression in cancer cells, which may contribute to its role in regulating cell cycle progression [21,22].

The secreted protein acidic and rich in cysteine (SPARC) over expression may play an important role in the initiation and development of NSCLC, whereas KLF4 inhibits this process [23]. Forced KLF4 expression inhibited cell growth and induced apoptosis. It is conceivable that KLF4 is able to enhance the sensitivity of cisplatin to lung cancer cells and the direct transcriptional targets of KLF4 also included vimentin, b-catenin, and VEGF-A [24]. K-ras mutation combined with Klf4 deletion significantly enhanced lung tumor formation. What's more, Klf4 deletion in conjunction with K-ras activation caused lung inflammation, which is partly responsible for the lung tumor formation. Class I histone deacetylases (HDACs) are over expressed in lung cancer and that HDAC inhibitors induced expression of KLF4 and inhibited proliferation of lung cancer cells, suggesting that KLF4 is probably repressed by histone acetylation [25].

\section{Regulation of KLF4}

Numbl-mediated tumorigenesis involved suppression of KLF4 "stemness" transcriptional program, thereby preserving a pool of progenitor-like cells in lung cancer and Numbl-Klf4 signaling is critical to maintain multiple nodes of metastatic progression, including persistence of cancer-initiating cells [26]. Both NLK knockdown and metformin treatment decreased the expressions of KLF4, Nanog, and c-Myc significantly, leading to the decrease of cancer stem cell stemness [27]. Elevated HOTAIR expression upregulated expression of the tumor stem cell related biomarkers KLF4, Nanog, Oct3/4, Sox2, c-Myc, and $\beta$-catenin [28]. What's more, Interleukin-27 down-regulated stemness-related genes including KLF4, and inhibited EMT of lung cancer cells [29]. Many aggressive tumors, including lung cancer, have been shown to display gene expression signatures characteristic of human embryonic stem cells (hESC). Hypoxia, through hypoxia-inducible factor (HIF), can induce an hESClike transcriptional program, including the induced pluripotent stem cell inducers, KLF4, OCT4, NANOG, SOX2, cMYC, and microRNA-302 in lung cancer and other 10 cancer cell lines [30].

In distal lung vascular smooth muscle cells (VSMCs), miR29 promotes the differentiation of VSMCs by targeting KLF4 and the PDGF pathway [31]. In addition, miR-10b [32,33] and miR-7 [34] may promote proliferation and invasiveness of lung cancer cells by down regulating the expression of KLF4 protein. Hypermethylation of the KLF4 promoter was thought to be associated with its transcriptional repression in a study, while some other researchers did not agree with that. Further study is needed to find whether hypermethylation of KLF4 promoter contribute to the process.

\section{Conclusion}

KLF4 is a transcription factor expressed in a wide variety of tissues in humans and is important in many different physiologic processes, including development, proliferation, differentiation, and apoptosis [35]. KLF4 can either activate or repress transcription depending on the target gene by utilizing different mechanisms. The expression of KLF4 appears to exert a dual effect on lung cancer, depending on the cell context and gene network.

The identification of proteins or transcription factors with altered expression as a manifestation of human lung carcinogenesis is important in the discovery of biomarkers for early detection of lung cancer. More data supported that the protein level of KLF4 expression was significantly decreased in NSCLC compared with that in normal tissue, while significant over expression was detected in SCLC, which represents the fast-growing nature of this type of lung cancer that is considered highly lethal. These findings suggest that KLF4 may play a role in the carcinogenic process. Advanced lung adenocarcinom as exhibited significantly higher rates of KLF4 expression compared with stage I disease, where the expression of KLF4 was absent.

Many factors are involved in the network of KLF4 in lung cancer. So far, we have limited data on the research of KLF4 in lung cancer: KLF4 has been demonstrated to down-regulate p21, SPARC, vimentin, b-catenin, and VEGF-A, but to up-regulate cyclin D1, and it may enhance the lung tumor formation combined with K-ras mutation. Moreover, Numbl, NLK, Interleukin-27, miR-7, miR-10b, and miR-29 decreased the expressions of KLF4, while HOTAIR and HIF elevated the expression of KLF4. Looking at the whole research concerning KLF4, it is known that more than 65 factors regulate KLF4 expression and more than 65 factors or pathways are regulated by KLF4 [36], so we still have a lot to know about the function of KLF4 in lung cancer. 
In clinical trials and practice, several drugs targeting the microenvironment have been tested including targets such as VEGF and its receptors on NSCLC-associated endothelial cells [37] and some of the drugs have brought clinical benefit for lung cancer patients. As KLF4 has been continuingly studied in lung cancer, there is hope that in the near future, we could know more about the prognostic and therapeutic value of KLF4 in lung cancer.

\section{Acknowledgment}

\section{Funding}

Our work was supported by funds from the Health and Family Planning Commission of Zhejiang Province Science Funding Project grant no.2017181152 and the Zhejiang Province Administration of Traditional Chinese Medicine grant no.2017ZQ019.

\section{References}

1. Shields JM, RJ Christy, Yang VW (1996) Identification and characterization of a gene encoding a gut-enriched Kruppel-like factor expressed during growth arrest. J Biol Chem 271(33): 20009-20017.

2. Garrett-Sinha LA, Eberspaecher H, Seldin MF, de Crombrugghe B (1996) A gene for a novel zinc-finger protein expressed in differentiated epithelial cells and transiently in certain mesenchymal cells. J Biol Chem 271(49): 31384-31390.

3. Panigada M, Porcellini S, Sutti F, Doneda L, Pozzoli O, et al. (1999) GKLF in thymus epithelium as a developmentally regulated element of thymocyte-stroma cross-talk. Mech Dev 81(1-2): 103-113.

4. Cullingford TE, Butler MJ, Marshall AK, Tham el L, Sugden PH, et al. (2008) Differential regulation of Kruppel-like factor family transcription factor expression in neonatal rat cardiac myocytes: effects of endothelin-1, oxidative stress and cytokines. Biochim Biophys Acta 1783(6): 1229-1236.

5. Fruman DA, Ferl GZ, An SS, Donahue AC, Satterthwaite AB, et al. (2002) Phosphoinositide 3-kinase and Bruton's tyrosine kinase regulate overlapping sets of genes in B lymphocytes. Proc Natl Acad Sci 99(1): 359-364.

6. Garrett-Sinha LA, Eberspaecher H, Seldin MF, de Crombrugghe B, et al. (1996) A gene for a novel zinc-finger protein expressed in differentiated epithelial cells and transiently in certain mesenchymal cells. J Biol Chem 271(49): 31384-31390.

7. Ton-That H, Kaestner KH, Shields JM, Mahatanankoon CS, Yang VW, et al. (1997) Expression of the gut-enriched Kruppel-like factor gene during development and intestinal tumorigenesis. FEBS Lett 419(2-3): 239-243.

8. Katz JP, Perreault N, Goldstein BG, Lee CS, Labosky PA, et al. (2002) The zinc-finger transcription factor Klf4 is required for terminal differentiation of goblet cells in the colon. Development 129(11): 2619-2628.

9. Jean JC, George E, Kaestner KH, Brown LA, Spira A, et al. (2013) Transcription factor Klf4, induced in the lung by oxygen at birth, regulates perinatal fibroblast and myofibroblast differentiation. PLOS One 8(1): e54806.

10. Takahashi K, Tanabe K, Ohnuki M, Narita M, Ichisaka T, et al. (2007) Induction of pluripotent stem cells from adult human fibroblasts by defined factors. Cell 131(5): 861-872.

11. Takahashi K, Yamanaka S (2006) Induction of pluripotent stem cells from mouse embryonic and adult fibroblast cultures by defined factors. Cell 126(4): 663-676.
12. Wei D, Gong W, Kanai M, Schlunk C, Wang L, et al. (2005) Drastic downregulation of Kruppel-like factor 4 expression is critical in human gastric cancer development and progression. Cancer Res 65(7): 27462754.

13. Wei D, Kanai M, Huang S, Xie K (2006) Emerging role of KLF4 in human gastrointestinal cancer. Carcinogenesis 27(1): 23-31.

14. Ohnishi S, Ohnami S, Laub F, Aoki K, Suzuki K, et al. (2003) Downregulation and growth inhibitory effect of epithelial-type Kruppel-like transcription factor KLF4, but not KLF5, in bladder cancer. Biochem Biophys Res Commun 308(2): 251-256.

15. Nakahara Y, Northcott PA, Li M, Kongkham PN, Smith C, et al. (2010) Genetic and epigenetic inactivation of Kruppel-like factor 4 in medulloblastoma. Neoplasia 12(1): 20-27.

16. Foster KW, Frost AR, McKie-Bell P, Lin CY, Engler JA, et al. (2000) Increase of GKLF messenger RNA and protein expression during progression of breast cancer. Cancer Res 60(22): 6488-6495.

17. Chen YJ, Wu CY, Chang CC, Ma CJ, Li MC, et al. (2008) Nuclear Kruppellike factor 4 expression is associated with human skin squamous cell carcinoma progression and metastasis. Cancer Biol Ther 7(5): 777782 .

18. Hu W, Hofstetter WL, Li H, Zhou Y, He Y, et al. (2009) Putative tumor-suppressive function of Kruppel-like factor 4 in primary lung carcinoma. Clin Cancer Res 15(18): 5688-5695.

19. Naranjo GJ, Bernal JF, Arranz PG, Fernández SL, Roman JJ, et al. (2014) Alterations in the expression of p53, KLF4, and p21 in neuroendocrine lung tumors. Arch Pathol Lab Med 138(7): 936-942.

20. Fadous-Khalife MC, Aloulou N, Jalbout M, Hadchity J, Aftimos G, et al. (2016) Kruppel-like factor 4: A new potential biomarker of lung cancer. Mol Clin Oncol 5(1): 35-40.

21. Zhang W, Geiman DE, Shields JM, Dang DT, Mahatan CS, et al. (2000) The gut-enriched Kruppel-like factor (Kruppel-like factor 4) mediates the transactivating effect of $\mathrm{p} 53$ on the $\mathrm{p} 21 \mathrm{WAF} 1 / \mathrm{Cip} 1$ promoter. J Biol Chem 275(24): 18391-18398.

22. Shie JL, Chen ZY, Fu M, Pestell RG, Tseng CC (2000) Gut-enriched Kruppel-like factor represses cyclin D1 promoter activity through Sp1 motif. Nucleic Acids Res 28(15): 2969-2976.

23. Zhang Z, Wang Z, Liu X, Shi M, Chen G, et al. (2012) [Correlation of KLF4 and SPARC expression with the clinical characteristics of non-small cell lung cancer]. Zhongguo Fei Ai Za Zhi 15(12): 720-724.

24. Tiwari N, Meyer-Schaller N, Arnold P, Antoniadis H, Pachkov M, et al. (2013) Klf4 is a transcriptional regulator of genes critical for EMT, including Jnk1 (Mapk8). PLoS One 8(2): e57329.

25. Yu T, X Chen, W Zhang, J Liu, R Avdiushko, et al. (2016) KLF4 regulates adult lung tumor-initiating cells and represses K-Ras-mediated lung cancer. Cell Death Differentiation. 23(2): 207-215.

26. Vaira V, Faversani A, Martin NM, Garlick DS, Ferrero S, et al. (2013) Regulation of lung cancer metastasis by Klf4-Numb-like signaling. Cancer Res 73(8): 2695-2705.

27. Suwei D, Liang Z, Zhimin L, Ruilei L, Yingying Z, et al. (2015) NLK functions to maintain proliferation and stemness of NSCLC and is a target of metformin. Journal of Hematol Oncol 8:120.

28. Liu MY, Li XQ, Gao TH, Cui Y, Ma N, et al. (2016) Elevated HOTAIR expression associated with cisplatin resistance in non-small cell lung cancer patients. J Thorac Dis 8(11): 3314-3322.

29. Airoldi I, Tupone MG, Esposito S, Russo MV, Barbarito G, et al. (2015) Interleukin-27 re-educates intratumoral myeloid cells and downregulates stemness genes in non-small cell lung cancer. Oncotarget 6(6): 3694-3708.

30. Mathieu J, Zhang Z, Zhou W, Wang AJ, Heddleston JM, et al. (2011) HIF 
induces human embryonic stem cell markers in cancer cells. Cancer Res 71(13): 4640-4652.

31. Cushing L, Costinean S, Xu W, Jiang Z, Madden L, et al. (2015) Disruption of miR-29 Leads to Aberrant Differentiation of Smooth Muscle Cells Selectively Associated with Distal Lung Vasculature. PLOS Genetics 11(5): e1005238.

32. Liu Y, Li M, Zhang G, Pang Z (2013) MicroRNA-10b over expression promotes non-small cell lung cancer cell proliferation and invasion. Eur J Med Res 18: 41

33. Su QL, Li SQ, Wang DN, Liu F, Yuan B (2014) Effects of MicroRNA$10 \mathrm{~b}$ on lung cancer cell proliferation and invasive metastasis and the underlying mechanism. Asian Pac J Trop Med 7(5): 364-367.

34. Meza-Sosa KF, Pérez-García EI, Camacho-Concha N, López-Gutiérrez O, Pedraza-Alva G, et al. (2014) MiR-7 promotes epithelial cell transformation by targeting the tumor suppressor KLF4. PLoS One 9(9): e103987.

35. Dang DT, Pevsner J, Yang VW (2000) The biology of the mammalian Kruppel-like family of transcription factors. Int J Biochem Cell Biol 32(11-12): 1103-21.

36. El-Nikhely N, Larzabal L, Seeger W, Calvo A, Savai R, et al. (2012) Tumor-stromal interactions in lung cancer: novel candidate targets for therapeutic intervention. Expert Opin Investig Drugs. 21(8): 11071122.

37. Sandler A, Gray R, Perry MC, Brahmer J, Schiller JH, et al. (2006) Paclitaxel-carboplatin alone or with bevacizumab for non-small-cell lung cancer. N Engl J Med 355(24): p. 2542-2550.

This work is licensed under Creative Commons Attribution 4.0 Licens DOI: 10.19080/IJOPRS.2017.01.555575 will reach you the below assets

\section{Your next submission with Juniper Publishers}

- Quality Editorial service

- Swift Peer Review

- Reprints availability

- E-prints Service

- Manuscript Podcast for convenient understanding

- Global attainment for your research

- Manuscript accessibility in different formats ( Pdf, E-pub, Full Text, Audio)

- Unceasing customer service

Track the below URL for one-step submission https://juniperpublishers.com/online-submission.php 